\title{
PENGARUH THERAPY GUIDED IMAGERY TERHADAP TINGKAT NYERI PADA PASIEN POST OPERASI SECTIO CAESAREA DI RUMAH SAKIT TK. II PELAMONIA MAKASSAR
}

\author{
Erawati $^{1}$, Jamila Kasim ${ }^{2}$, Ernawati Askar ${ }^{3}$ \\ ${ }^{1}$ STIKES Nani Hasanuddin Makassar \\ ${ }^{2}$ STIKES Nani Hasanuddin Makassar \\ ${ }^{3}$ STIKES Nani Hasanuddin Makassar
}

Alamat Korespondensi : (nauraerawati512@gmail.com/082199498537)

\begin{abstract}
ABSTRAK
Sectio caesarea merupakan kelahiran janin melalui jalur abdominal (laparotomi) yang memerlukan insisi ke dalam uterus (histerotomi). Adanya insisi dan jaringan yang rusak menyebabkan sensasi rasa nyeri. Nyeri sangat mengganggu dan menyulitkan lebih banyak responden dibanding suatu penyakit manapun. Perawat berperan besar dalam penanggulangan nyeri non farmakologis. Tujuan penelitian adalah untuk mengetahui pengaruh therapy guided imagery terhadap penurunan intensitas nyeri pada pasien post operasi sectio caesarea di Rumah Sakit TK. II Pelamonia Makassar. Penelitian ini menggunakan metode penelitian Pre-experimental Design dengan jenis rancangan yang digunakan One Group Pretest-Postest Design dan dilaksanakan di Ruang PNC Rumah Sakit Tk. II Pelamonia Makassar pada tanggal 01 sampai 22 Desember 2018. Populasi dalam penelitian ini adalah semua pasien post operasi caesarea yang dirawat di Ruang PNC Rumah Sakit TK. II Pelamonia Makassar. Metode pengambilan sampel yang digunakan adalah total sampling dengan jumlah sampel sebanyak 11 pasien. Hasil penelitian ini menunjukkan bahwa skor rata-rata tingkat nyeri responden sebelum therapy guided imagery yaitu 7 , dimana skor tingkat nyeri tertinggi yaitu 8 dan terendah 6 , sedangkan skor rata-rata tingkat nyeri responden sesudah therapy guided imagery yaitu 4 , dimana skor tingkat nyeri tertinggi yaitu 8 dan terendah 6 . Hasil uji Wilcoxon diperoleh nilai $\rho=0,002$, yang berarti nilai $\rho$ lebih kecil dari nilai $(\alpha) 0,05$, dengan demikian $\mathrm{HO}$ ditolak dan Ha diterima. Kesimpulan penelitian ini adalah ada pengaruh therapy guided imagery terhadap tingkat nyeri pada pasien post operasi sectio caesarea di Rumah Sakit TK. II Pelamonia Makassar.
\end{abstract}

\section{Kata Kunci : Intensitas Nyeri, Therapy Guided Imagery}

\section{PENDAHULUAN}

Bedah atau pembedahan (bahasa inggris: Surgery, bahasa Yunani Cheirourgia (pekerjaan tangan) adalah spesialis dalam kedokteran yang mengobati penyakit atau luka dengan operasi manual dan instrument. Menurut R. Sjamsuhidajat dan Wim De Jong, 2005, pembedahan atau operasi adalah semua tindakan pengobatan yang menggunakan cara invasif dengan membuka atau menampilkan bagian tubuh yang akan ditangani (Maryunani, 2014).

Nyeri adalah alasan utama seseresponden untuk mencari bantuan perawatan kesehatan. Nyeri terjadi bersama banyak proses penyakit atau bersamaan dengan beberapa pemeriksaan diagnostik atau pengobatan. Nyeri sangat mengganggu dan menyulitkan lebih banyak responden dibanding suatu penyakit manapun. Perawat berperan besar dalam penanggulangan nyeri non farmakologis. Salah satu penanggulangan nyeri non farmakologis yang mudah dalam mengatasi nyeri akibat kerusakan jaringan akibat tindakan pembedahan adalah teknik relaksasi (Lukman, 2013).

Berdasarkan data dari Media Centre of WHO, sekitar 830 wanita meninggal setiap hari karena komplikasi kehamilan atau persalinan pada tahun 2015. Mengurangi rasio kematian ibu dari 216 per 100.000 kelahiran hidup pada tahun 2015 menjadi kurang dari 70 per 100.000 pada tahun 2030 akan memerlukan lebih dari tiga kali lipat tingkat penurunan tahunan rata-rata Antara tahun 1990 dan 2015 (Jašarević \& Bennett, 2017).

Beradsarkan data Profil Kesehatan Indonesia, menunjukkan penurunan AKI di Indonesia terjadi sejak tahun 1991 sampai dengan 2007, yaitu dari 390 menjadi 228. Namun demikian, SDKI tahun 2012 menunjukkan peningkatan AKI yang signifikan yaitu menjadi 359 kematian ibu per 100.000 kelahiran hidup. AKI kembali menujukkan penurunan menjadi 305 kematian ibu per 100.000 kelahiran hidup berdasarkan hasil Survei Penduduk Antar Sensus (SUPAS) 2015 (Kementerian Kesehatan RI, 2017). 
Berdasarkan data dari Dinas Kesehatan Sulawesi Selatan, menunjukkan jumlah kematian ibu tahun 2016 yang dilaporkan menjadi 153 responden atau 103.00 per 100.000 kelahiran hidup, terdiri dari kematian ibu hamil 47 responden $(30,71 \%)$, kematian ibu bersalin 44 responden $(27,45 \%)$, kematian ibu nifas 62 responden $(40,52 \%)$, adapun kematian ibu menurut umur yaitu $<20$ tahun sebanyak 7 responden, umur 20-34 tahun sebanyak 101 responden, dan $\geq 35$ tahun sebanyak 45 responden (Dinkes Sulsel, 2017).

Salah satu cara untuk menurunkan angka kematian dengan tindakan penyelamatan bayi serta ibunya dalam persalinan dengan cara operasi sectio caesarea (SC). Sectio caesarea merupakan kelahiran janin melalui jalur abdominal (laparotomi) yang memerlukan insisi ke dalam uterus (histerotomi). Adanya insisi dan jaringan yang rusak menyebabkan sensasi rasa nyeri. Sensasi nyeri yang dirasa tergantung pada persepsinya, dan persepsi setiap pasien terhadap nyeri berbeda-beda tergantung nilai ambang batas nyerinya. Sehingga respons terhadap nyeri juga berbeda-beda, ada yang berteriak, meringis dan lain-lain. Pilihan utama untuk mengatasi nyeri dewasa ini ialah dengan pemberian analgesik (Astutik \& Kurlinawati, 2017).

Berdasarkan data dari rumah sakit TK. II Pelamonia Makassar jumlah operasi sectio caesarea pada tahun 2016 berjumlah 246 kasus sedangkan pada tahun 2017 mengalami peningkatan sebanyak 261 kasus. Data dari Januari sampai dengan November tahun 2018 sebanyak 200 kasus (Rekam Medik RS TK.II Pelamonia, 2018).

Berdasarkan uraian tersebut, maka peneliti merasa perlu untuk melakukan penelitian tentang Pengaruh Therapy Guided Imagery Terhadap Tingkat Nyeri pada Pasien Post Operasi Sectio Caesarea di Rumah Sakit TK. II Pelamonia Makassar.

\section{BAHAN DAN METODE}

Lokasi, Populasi, dan Sampel

Penelitian yang telah dilakukan di Ruang PNC Rumah Sakit Tk. II Pelamonia Makassar pada tanggal 01 sampai 22 Desember 2018. Populasi dalam penelitian ini adalah semua pasien post operasi caesarea yang dirawat di Ruang PNC Rumah Sakit TK. II Pelamonia Makassar sebanyak 11 pasien dengan jumlah sampel sebanyak 11 pasien.

Pengumpulan data

1. Pengumpulan data primer diperoleh dengan menggunakan lembar observasi yang telah disediakan.
2. Pengumpulan data sekunder diperoleh dari Rekam Medik RS TK. II Pelamonia Makassar

\section{Pengolahan Data}

1. Editing

Hasil angket yang diperolehkan atau dikumpulkan melalui kuesioner perlu disunting (edit) terlebih dahulu. Kalau tenyata masih ada data atau informasi yang tidak lengkap, dan tidak mungkin dilakukan wawancara ulang, maka kuesioner tersebut dikeluarkan (drop out).

2. Coding sheet

Lembaran kode adalah instrument berupa kolom untuk merekam data secara manual. Lembaran atau kartu kode berisi nomor responden, dan nomor pertanyaan.

3. Data entry

Yakni mengisi kolom atau kotak lembar atau kartu kode sesuai dengan jawaban masing-masing pertanyaan.

4. Tabulasi

Yakni membuat tabel data, sesuai dengan tujuan penelitian atau yang diinginkan oleh peneliti

\section{Analisa Data}

3. Analisis Univariat

Analisa univariat bertujuan untuk mendeskripsikan karakteristik setiap variabel penelitian. Bentuk jenis analisis univariat tergantung dari jenis datanya.

4. Analisis Bivariat

Analisis bivariat yang dilakukan terhadap dua variabel yang diduga berhubungan atau berkorelasi (Notoatmodjo, Metodologi Penelitian Kesehatan, 2014).

\section{HASIL PENELITIAN}

3. Analisis Univariat Distribusi Karakteristik Responden di Ruang PNC Rumah Sakit TK. II Pelamonia Makassar $(n=11)$

\begin{tabular}{|c|c|c|}
\hline Karakteristik & $\mathrm{n}$ & $\%$ \\
\hline Umur & & \\
17-25 tahun & 1 & 9,1 \\
26-35 tahun & 10 & 90,9 \\
\hline Pendidikan & & \\
DIII & 7 & 63,6 \\
S1 & 4 & 36,4 \\
\hline Pekerjaan & & \\
IRT & 10 & 90,9 \\
PNS & 1 & 9,1 \\
\hline Paritas & & \\
Primigravida & 1 & 9,1 \\
Multigravida & 10 & 90,9 \\
\hline
\end{tabular}


Berdasarkan tabel diatas menunjukkan bahwa umur responden terbanyak adalah 26-35 tahun yaitu sebanyak 10 responden (90,9\%). Pendidikan terbanyak adalah DIII yaitu sebanyak 7 responden (63,6\%). Pekerjaan terbanyak adalah IRT yaitu sebanyak 10 responden (90,9\%). Paritas terbanyak adalah IRT yaitu sebanyak 10 responden $(90,9 \%)$.

4. Analisis bivariat

Pengaruh Therapy Guided Imagery Terhadap Tingkat Nyeri pada Pasien Post Operasi Sectio Caesarea di Rumah Sakit TK. II Pelamonia Makassar $(n=11)$

\begin{tabular}{|c|c|c|}
\hline Tingkat nyeri & $\begin{array}{c}\text { Median } \\
\text { (Min- } \\
\text { Max) }\end{array}$ & Sig (p) \\
\hline $\begin{array}{c}\text { Sebelum therapy } \\
\text { guided imagery } \\
\text { Sesudah therapy } \\
\text { guided imagery }\end{array}$ & 4 (6-8) & 0,002 \\
\hline $\begin{array}{l}\text { Wilcoxon, 11 subjek skor tingkat nyeri } \\
\text { menurun, 0 tetap dan 0 meningkat }\end{array}$ & \\
\hline
\end{tabular}

Berdasarkan tabel di atas menunjukkan bahwa skor rata-rata tingkat nyeri responden sebelum therapy guided imagery yaitu 7 , dimana skor tingkat nyeri tertinggi yaitu 8 dan terendah 6 , sedangkan skor rata-rata tingkat nyeri responden sesudah therapy guided imagery yaitu 4, dimana skor tingkat nyeri tertinggi yaitu 8 dan terendah 6. Hasil uji Wilcoxon diperoleh nilai $\rho=0,002$, yang berarti nilai $\rho$ lebih kecil dari nilai (a) 0,05, dengan demikian $\mathrm{HO}$ ditolak dan $\mathrm{Ha}$ diterima. Interpretasi ada pengaruh therapy guided imagery terhadap tingkat nyeri pada pasien post operasi sectio caesarea di Rumah Sakit TK. II Pelamonia Makassar.

\section{PEMBAHASAN}

Berdasarkan penelitian yang telah dilakukan di Ruang PNC Rumah Sakit Tk. II Pelamonia Makassar menunjukkan bahwa skor rata-rata tingkat nyeri responden sebelum therapy guided imagery yaitu 7, dimana skor tingkat nyeri tertinggi yaitu 8 dan terendah 6 , sedangkan skor rata-rata tingkat nyeri responden sesudah therapy guided imagery yaitu 4, dimana skor tingkat nyeri tertinggi yaitu 8 dan terendah 6 .

Dalam penelitian ini terdapat 11 responden yang mengalami penuruan skor tingkat nyeri setelah pemberian therapy guided imagery. Adanya penurunan yang signifikan dalam penelitian ini karena kombinasi antara pemberian teknik guided imagery dalam dengan pemberian obat farmakologi sehingga dapat memberikan perubahan yang baik terhadap penurunan skor tingkat nyeri.

Hasil uji Wilcoxon diperoleh nilai z sebesar $-3,025$ dengan nilai $\rho=0,002$, yang berarti nilai $\rho$ lebih kecil dari nilai $(\alpha) 0,05$, dengan demikian $\mathrm{HO}$ ditolak dan $\mathrm{Ha}$ diterima. Interpretasi ada pengaruh therapy guided imagery terhadap tingkat nyeri pada pasien post operasi sectio caesarea di Rumah Sakit TK. II Pelamonia Makassar.

Hasil penelitian ini sejalan dengan penelitian yang telah dilakukan oleh Patasik, dkk., (2013) dengan judul Efektifitas Teknik Relaksasi Nafas Dalam dan Guided Imagery Terhadap Penurunan Nyeri pada Pasien Post Operasi Sectio Caesare di Irina D BLU RSUP Prof. Dr. R. D. Kandou Manado menunjukkan bahwa tingkat nyeri pada pasien post operasi sectio caesarea sebelum dilakukan teknik guided imagery di Irina D BLU RSUP Prof. Dr. R. D. Kandou Manado sebagian besar mengalami nyeri hebat sampai sangat hebat, tingkat nyeri pada pasien post operasi sectio caesarea sesudah dilakukan teknik guided imagery di Irina D BLU RSUP Prof. Dr. R. D. Kandou Manado sebagian besar mengalami penurunan ke kategori nyeri ringan selebihnya ke kategori nyeri sedang, guided imagery efektif terhadap penurunan nyeri pada pasien post operasi sectio caesarea.

Penelitian yang telah dilakukan oleh Suarilah, dkk., (2014) dengan judul Guided Imagery and Music (GIM) Menurunkan Intensitas Nyeri Pasien Post Sectio Caesarea Berbasis Adaptasi Roy menunjukkan bahwa ada perbedaan intensitas nyeri yang signifikan antara pasien post Sectio Caesarea pada kelompok kontrol setelah diberikan analgesik non opioid dengan kelompok perlakuan setelah diberikan analgesik non opioid dan Guided Imagery and Music (GIM). GIM terbukti dapat menurunkan intensitas nyeri pasien post Sectio Caesarea di RSUP NTB. Penurunan intensitas nyeri tampak lebih besar pada kelompok perlakuan dibandingkan dengan kelompok kontrol. Hal ini disebabkan karena pada kelompok perlakuan selain diberikan analgesik non opioid juga diberikan guided imagery and music (GIM) oleh peneliti. Menggabungkan intervensi farmakologis dengan nonfarmakologis merupakan cara yang paling tepat untuk menurunkan nyeri.

Guided imagery juga disebut visualisasi kreatif, merupakan penggunaan pikiran untuk membentuk pamandangan atau pengalaman sensori yang merelaksasikan otot dan menjauhkan perhatian pikiran dari pengalaman nyeri. Pemandangan dapat 
dibuat oleh peneliti untuk membantu pasien memodifikasi respon fisik terhadap stressor nyeri. Untuk menggunakan guided imagery pasien harus mampu berkonsentrasi, menggunakan imajinasi dan mengikuti petunjuk. Perawat dapat memfasilitasi tekhnik ini dengan menanyakan pasien beberapa gambaran tentang sesuatu yang ditemukan pasien sebagai hal yang paling merelaksasikan. Perawat kemudian berbicara kepada pasien dengan tenang, suara yang tenang tentang tempat atau situasi tersebut. Imaginasi dapat menyebabkan perubahan tanda-tanda vital, pola gelombang otak, aliran darah, serta kadar hormon dan neurotransmitter (Fontaine, 2005) dalam (Lemone, dkk., 2016).

Sedangkan merunut Rosdahl \& Kowalski (2014) guided imagery adalah suatu proses klien menerima anjuran untuk berkonsentrasi pada sebuah gambar untuk mengontrol nyeri atau ketidaknyamanan. Latihan relaksasi dalam dilakukan terlebih dahulu, sehingga klien relaks sepenuhnya. Kemudian klien dibimbing melalui gambaran spesifik. Misalnya, anjuran mungkin berupa kata-kata bahwa nyeri terjadi di area tubuh yang besar lalu bergerak turun dan keluar dari tubuh.

Menurut asumsi peneliti, pemberian therapy guided imagery berpengaruh terhadap tingkat nyeri pada pasien post operasi sectio caesarea. Karena dari hasil penelitian membuktikan adanya penurunan dilihat dari nilai intensitas, tetapi faktor kombinasi antara pemberian therapy guided imagery dengan pemberian obat farmakologi seperti ketorolac dapat memberikan perubahan yang baik terhadap penurunan intersitas nyeri dan nyeri dapat menurun tanpa menunggu waktu yang lama. Therapy guided imagery mempengaruhi sistem kontrol desendens yang berfungsi dalam pelepasan endorfin. Endorfin merupakan sebuah substansi yang bekerja untuk menghambat proses pengiriman impuls nyeri ke sistem saraf pusat.

\section{KESIMPULAN}

1. Rata-rata skor tingkat nyeri pasien post operasi sectio caesarea sebelum diberikan therapy guided imagery di Rumah Sakit Tk. II Pelamonia Makassar yaitu skor 7 .

2. Rata-rata skor tingkat nyeri pasien post operasi sectio caesarea sesudah diberikan therapy guided imagery di Rumah Sakit Tk. II Pelamonia Makassar yaitu skor 4.

3. Ada pengaruh therapy guided imagery terhadap tingkat nyeri pada pasien post operasi sectio caesarea di Rumah Sakit TK. II Pelamonia Makassar.

\section{SARAN}

1. Diharapkan perawat memberikan tambahan intervensi dengan therapy guided imagery pada pasein post operasi sectio caesarea sesuai dengan tahap tingkatan nyeri yang dihadapi klien, karena hasilnya dapat membantu petugas kesehatan dalam memberikan intervensiintervensi berikutnya.

2. Diharapkan rumah sakit melakukan program therapy guided imagery demi menurunkan intensitas nyeri pada post operasi sectio caesarea yang menjalani perawatan.

3. Diharapkan peneliti selanjutnya dapat meneliti lebih dalam dan lebih jauh lagi serta menggunakan uji yang berbeda sehingga didapatkan hasil yang lebih signifikan

\section{DAFTAR PUSTAKA}

Astutik, P., \& Kurlinawati, E. (2017). Pengaruh Relaksasi Genggam Jari Terhadap Penurunan Nyeri Pada Pasien Post Sectio Caesarea Di Ruang Delima RSUD Kertosono. Jurnal IImiah Kesehatan, Vol. 6 No. 2.

Dinkes Sulsel. (2017). Profil Kesehatan Kesehatan Provinsi Sulawesi Selatan Tahun 2016. Makassar: Dinas Kesehatan Sulawesi Selatan.

Jašarević, T., \& Bennett, S. (2017). Almost Half of All Deaths Now Have A Recorded Cause, WHO Data Show. Geneva: Media Centre of WHO.

Kementerian Kesehatan RI. (2017). Profil Kesehatan Indonesia Tahun 2016. Jakarta: Kementerian Kesehatan Republik Indonesia.

Lemone, P., Burke, K., \& Bauldoff, G. (2016). Buku Ajar Keperawatan Medikal Bedah. Jakarta: EGC.

Lukman, T. V. (2013). Pengaruh Teknik Relaksasi Nafas Dalam Terhadap Intensitas Nyeri pada Pasien PostOperasi Sectio Caesaria di RSUD. Prof. Dr. Hi. Aloei Saboe Kota Gorontalo. Jurnal Online.

Maryunani, A. (2014). Asuhan Keperawatan Perioperatif - Pre Operasi (Menjelang Pembedahan). Jakarta: Trans Info Media. 
Notoatmodjo, S. (2014). Metodologi Penelitian Kesehatan. Jakarta: PT. Rineka Cipta.

Patasik, C. K., Tangka, J., \& Rottie, J. (2013). Efektifitas Teknik Relaksasi Nafas Dalam dan Guided Imagery Terhadap Penurunan Nyeri pada Pasien Post Operasi Sectio Caesare di Irina D BLU RSUP Prof. Dr. R. D. Kandou Manado. ejurnal keperawatan (e-Kp) Volume 1. Nomor 1.

Rosdahl, C. B., \& Kowalski, M. T. (2014). Buku Ajar Keperawatan Dasar. Jakarta: EGC.

Suarilah, I., Wahyuni, E., \& Falupi, R. (2014). Guided Imagery and Music (GIM) Menurunkan Intensitas Nyeri Pasien Post Sectio Caesarea Berbasis Adaptasi Roy. Jurnal Keperawatan Universitas Airlangga. 